\title{
Distribution of gaseous Hg in the Mercury mining district of Mt. Amiata (Central Italy): A geochemical survey prior the reclamation project
}

\author{
Orlando Vaselli ${ }^{\mathrm{a}, \mathrm{b}, *}$, Pablo Higueras ${ }^{\mathrm{c}}$, Barbara Nisi ${ }^{\mathrm{d}}$, José María Esbrí ${ }^{\mathrm{c}}$, Jacopo Cabassi ${ }^{\mathrm{a}}$, \\ Alba Martínez-Coronado ${ }^{c}$, Franco Tassi ${ }^{\mathrm{a}, \mathrm{b}}$, Daniele Rappuoli ${ }^{\mathrm{e}}$ \\ a Dipartimento di Scienze della Terra, Via G. Pira, 4, 50121 Firenze, Italy \\ ${ }^{\mathrm{b}}$ CNR-IGG Istituto di Geoscienze e Georisorse, Via G. Pira, 4, 50121 Firenze, Italy \\ ' Instituto de Geología Aplicada, Laboratorio de Biogeoquímica de Metales Pesados, Universidad de Castilla-La Mancha, 13400 Almadén (Ciudad Real), Spain \\ d CNR-IGG Istituto di Geoscienze e Georisorse, Via Moruzzi 56124 Pisa, Italy \\ e Unione dei Comuni Amiata-Val D’Orcia, Via del Colombaio, 98-53023 Gallina, Castiglion d'Orcia (Siena), Italy
}

\section{A R T I C L E I N F O}

Available online 7 March 2013

Keywords:

Mt. Amiata

Atmospheric mercury

Continuous $\mathrm{Hg}$ measurements

Mercury atmospheric sources

\begin{abstract}
A B S T R A C T
The Mt. Amiata volcano is the youngest and largest volcanic edifice in Tuscany (central-northern Italy) and is characterized by a geothermal field, exploited for the production of electrical energy. In the past Mt. Amiata was also known as a world-class $\mathrm{Hg}$ district whose mining activity was mainly distributed in the central-eastern part of this silicic volcanic complex, and particularly in the municipality of Abbadia San Salvatore. In the present work we report a geochemical survey on $\mathrm{Hg}^{0}$ measurements

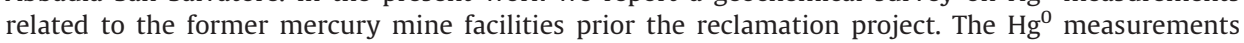
were carried out by car for long distance regional surveys, and on foot for local scale surveys by using two LUMEX $(915+$ and $\mathrm{M})$ devices. This study presents the very first $\mathrm{Hg}^{0}$ data obtained with this analytical technique in the Mt. Amiata area. The facilities related to the mining areas and structures where cinnabar was converted to metallic $\mathrm{Hg}$ are characterized by high $\mathrm{Hg}$ values $\left(>50,000 \mathrm{ng} \mathrm{m}^{-3}\right.$ ), although the urban center of Abbadia San Salvatore, few hundred meters away, does not appear to be receiving significant pollution from the calcine area and former industrial edifices, all the recorded values being below the values recommended by the issuing Tuscany Region authorities $\left(300 \mathrm{ng} \mathrm{m}^{-3}\right)$ and in some cases approaching the $\mathrm{Hg}$ background levels $\left(3-5 \mathrm{ng} \mathrm{m}^{-3}\right)$ for the Mt. Amiata area.
\end{abstract}

(c) 2013 Elsevier Inc. All rights reserved.

\section{Introduction}

The Mt. Amiata (1770 m a.s.l.) linear silicic complex, consisting of mafic enclaves-bearing dacitic, rhyodacitic and olivine-latitic rocks, is located in Central Italy (Fig. 1) and forms the most recent and the largest volcanic apparatus of the Tuscan Magmatic Province (e.g. Conticelli et al., 2004). It was formed between 300 and $190 \mathrm{ka}$ (Ferrari et al., 1996). This volcanic activity is likely related to the emplacement of a magmatic body in the Pliocene (e.g. Acocella, 2000 and references therein). The high heat flow in the area is due to a magmatic body located about $6-7 \mathrm{~km}$ below sea level and not completely cooled down that has produced a negative Bouguer anomaly and an uplift of about $1000 \mathrm{~m}$ of the surrounding Neogene sediments (Sestini, 1932; Gianelli et al., 1988). Two bi-phasic geothermal reservoirs are located in the carbonate-evaporite formations $\left(200-230^{\circ} \mathrm{C}\right)$ at the depth of

\footnotetext{
* Corresponding author at: Dipartimento di Scienze della Terra, Via G. Pira, 4, 50121 Firenze, Italy. Tel.: + 390552757508: fax: + 39055284571

E-mail address: orlando.vaselli@unifi.it (O. Vaselli).
}

$500-1000 \mathrm{~m}$ and in the metamorphic basal complex (up to $350{ }^{\circ} \mathrm{C}$ ) at depth $>3000 \mathrm{~m}$. At Piancastagnaio (Fig. 1) and Bagnore (SW of Mt. Amiata) these geothermal systems are exploited for the production of electrical energy by ENEL (National Energy for Electric Energy). At surface, the hydrothermal circulation is presently expressed by the many thermal $\mathrm{Ca}-\mathrm{SO}_{4}$ waters and $\mathrm{CO}_{2}\left(\mathrm{H}_{2} \mathrm{~S}\right)$-rich gas discharges that mainly discharge in the northeastern and south-western sectors of Mt. Amiata (Minissale et al., 1997; Frondini et al., 2009; Tassi et al., 2009) and represent an attraction for researchers and tourists (Vaselli et al., 2011).

Another peculiarity of this area is the $\mathrm{Hg}-\mathrm{Sb}$ metallogeny similar to that characterizing the whole Tuscany Region. According to Tanelli (1983), Dini et al. $(2001,2005)$ and Regoli and Berni (2001), the genesis of these ore deposits is related to a complex process of mobilization of $\mathrm{Sb}$ and $\mathrm{Hg}$ from Paleozoic phyllites in the Late Oligocene-Early Miocene, whilst in the PliocenePleistocene, antimony and mercury suffered a second mobilization that has produced in the Mt. Amiata the world-class epithermal deposits. This mobilization/deposition process is still active (Morteani et al., 2010). The ore-bearing fluids likely percolated through faults planes that acted as structural conduits. 


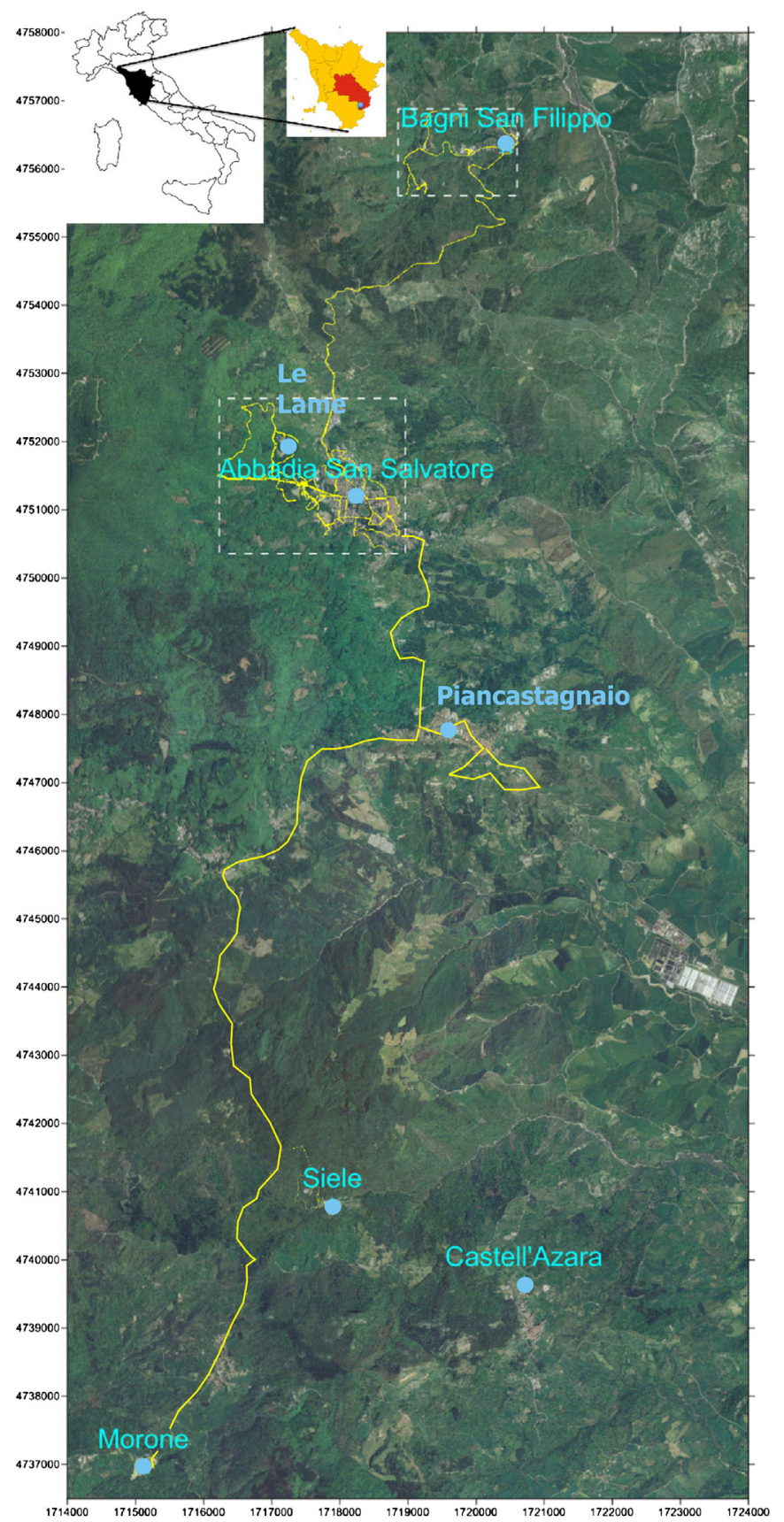

Fig. 1. Location of the study area. The two white dotted squares are the sites where the former mining area of Abbadia San Salvatore and the Bagni San Filippo hydrothermal system are located, respectively. The yellow paths indicate the roads where express surveys of atmospheric Hg were carried out. (For interpretation of the references to color in this figure legend, the reader is referred to the web version of this article.)

These normal fault zones functioned as connectors of two Pleistocene-Holocene left-lateral transtensional shear zones (Brogi et al., 2011).

Mercury in the Mt. Amiata mining district occurs as cinnabar (HgS) and was exploited since the Etruscan times (e.g. Strappa, 1977; Barghigiani and Ristori, 1994, Ferrara et al., 1991). However, it is in the second half of 1800 that the production of mercury abruptly increased and in 1925 more of the $50 \%$ of mercury worldwide was provided by the Mt. Amiata mining area (Cipriani and Tanelli, 1983) and about $70 \%$ of it was from the Abbadia San Salvatore district. Ferrara et al. (1998) reports that from 1860 to 1980 , when all $\mathrm{Hg}$ mines were definitively closed, more than $100,000 \mathrm{t}$ of $\mathrm{Hg}$ were produced in the Mt. Amiata mining district and it was classified as the 4th largest producing district in the world (Rimondi et al., 2012 and references within).

Areas in active and inactive mining extraction of $\mathrm{Hg}$ significantly contribute to the dispersion of this toxic element in the environment. The extraction of liquid mercury from cinnabar is generally carried out in retort or rotary furnaces where the reaction with $\mathrm{O}_{2}$ produces sulfur dioxide, as follows:

$\mathrm{HgS}+\mathrm{O}_{2} \rightarrow \mathrm{Hg}^{0}+\mathrm{SO}_{2}$

At temperatures higher than $350{ }^{\circ} \mathrm{C}$, mercury tends to vaporize and then it is condensed into its natural liquid state at room temperature. A further distillation at slightly higher temperatures favors the removal of the eventual remaining impurities. As a consequence, $\mathrm{Hg}$ mining areas may affect the territory where the extraction, preparation, heating and condensation processes are occurring, enhancing environmental concerns. Pollution can be derived by mine-waste calcines, usually containing high contents of $\mathrm{Hg}$ ( > $1000 \mathrm{mg} \mathrm{kg}^{-1}$; Gosar et al., 1997; Rytuba, 2000; Rytuba et al., 2001; Gray et al., 2002, 2004; Gray, 2003; Loredo et al., 2003; Zhang et al., 2004; Navarro et al., 2009) and related to unconverted cinnabar and formation of metacinnabar, $\mathrm{HgO}$ and other $\mathrm{Hg}$ salts (e.g. Kim et al., 2003; Gray et al., 2010 and references within) that interact with meteoric waters. Consequently, stream sediments and running waters from mercury mining systems are usually affected by significantly high $\mathrm{Hg}$ concentrations (e.g. Hines et al., 2000; Gray et al., 2002; Gray, 2003; Higueras et al., 2006, in press; Qiu et al., 2009, Rimondi et al., 2012). In these sites inorganic mercury can be converted to methyl-Hg (Boening, 2000): the toxic form of mercury to the living organisms. Aquatic biota has the capability to bioconcentrate methyl-Hg up to $10^{4}$ to $10^{7}$ times (Stein et al., 1996). It is also important to consider that time and soil inactivity may lead drastic reduction of $\mathrm{Hg}$ emissions (Higueras et al., 2012).

The Total Gaseous Mercury (TGM) is represented by the sum of anthropogenic and natural $\mathrm{Hg}$ emissions and related to elemental gaseous mercury (GEM) and gaseous oxidized mercury (GOM), while the solid component is named particulate bounded mercury (PBM) (e.g. Fu et al., 2012). GEM is the most abundant form of $\mathrm{Hg}$ in the atmosphere (>95\%), GOM and PBM being promptly deposited, due to its elevated stability and volatility and low solubility with a residence time of about $0.5-2$ years (Schroeder and Munthe, 1998; Lindberg et al., 2007). In active and abandoned mining areas, GEM may achieve high concentrations, being derived by: (i) contaminated terrains (e.g. Kocman et al., 2011), (ii) metallurgic processes (e.g. Wilson et al., 2006); (iii) abandoned mine structures and complexes (e.g. Grönlund et al., 2005) and (iv) remnants of the industrial production of $\mathrm{Hg}$ (e.g. Hylander and Meili, 2003).

In Abbadia San Salvatore the mining activity was developed in a surface of about 65 ha and includes about 90 edifices and mining structures. A reclamation project was submitted to the Tuscany Region authorities and the very first actions, mainly related to the removal of old asbestos-bearing roofs, have started in 2011. However, the $\mathrm{Hg}$-polluted areas are still to be cleaned.

It is a matter of fact that the Mt. Amiata area is characterized by an anomalous concentration of gaseous mercury due to the presence of ore mineralizations, former mining areas and geothermal plants. Many are the investigations carried out in different matrices such fishes (e.g. Bacci and Renzoni, 1973; Ferrara et al., 1991; Rimondi et al., 2012), plants (e.g. Ferrara et al., 1991; Bacci et al., 1994; Loppi, 2001; Loppi and Bonini, 2000), soils (e.g. Ferrara et al., 1991; 1997); stream sediments (e.g. Rimondi et al., 2012 and references therein) and waters (e.g. Ferrara et al., 1991; Rimondi et al., 2012). However, Hg data in the atmosphere surrounding the Mt. Amiata areas are relatively 
scanty and mainly related to the presence of As and $\mathrm{Hg}$ released from the geothermal plants that are located south of Abbadia San Salvatore (e.g. Ferrara et al., 1998 and references therein).

In this paper we present new original data on atmospheric mercury in the former $\mathrm{Hg}$ mining (outdoor and indoor) area of Abbadia San Salvatore and surrounding (urban and woodland) zones, including some sites where thermal water and gas discharges occur. The main goals were those to: (i) up-to-date and widen the atmospheric Hg data provided by Ferrara et al. (1998) by using for the first time in this area portable gaseous $\mathrm{Hg}$ analyzers for continuous mode measurements and (ii) provide contour maps in the Abbadia San Salvatore urban and mining areas that may be used prior the reclamation project.

\section{The former Mercury mining area}

The town of Abbadia San Salvatore was the most important site of exploitation of cinnabar and production of $\mathrm{Hg}$ in the whole Mt. Amiata $\mathrm{Hg}$ district. It is located in the eastern flank of the volcano. The exploited ore had a content of 0.6 to $2.0 \mathrm{wt} \%$ of $\mathrm{Hg}$ and was extracted up to the depth of $400 \mathrm{~m}$. Liquid mercury was produced after the ore mineral was dried, crushed and roasted at $650-700{ }^{\circ} \mathrm{C}$ from which it was condensed and then bottled. The roasting process was carried out with shaft Spirek and CermakSpirek furnaces, later replaced by tower furnaces connected to Cermak condensers and rotating furnaces (Gould and Pacific and Nesa). Part of $\mathrm{Hg}$ was also used for pigments and bottling and pigment production were carried out indoor (e.g. Bellander et al., 1998).

After the closure of the $\mathrm{Hg}$ mining activity, in the nineties the owner of the mining concession (E.N.I.: National Agency for Hydrocarbons, AGIP Division) produced a series of documentation for the reclamation of the $\mathrm{Hg}$ extraction and processing areas. In 2008, an agreement between E.N.I. and the municipality of Abbadia San Salvatore was signed in order to transfer the ownership of the reclamation to the public agency. One of the main aims of the agreement is that to address the remediation to an environmentally rehabilitation of the mining areas and buildings for museum purposes and public green. However, the cessation of the mining activities, which occurred without a scheduled basis, has left the decontamination issue open. Beside the mounds of mine tailings and calcines, mostly located at Le Lame (Fig. 1), there are mining structures around which more or less important quantities of metallic mercury have remained and are still to be eliminated.

In March 1995 the authorities of the Tuscany Region issued a regulation for the recovery of those areas characterized by mining and/or metallurgical processing. The Italian legislation, including the Legislative Decree 152/2006, did not repeal the regional laws, which were further developed and updated in the subsequent years, i.e. 1998, 1999 and 2004. In particular, regional decrees state that the concentration of mercury above contaminated soils has to be $<300 \mathrm{ng} \mathrm{m}^{-3}$. It is worthwhile to mention that the Regional Decree no. 1447 (23rd of November, 1998) assesses that at the end of the remediation in any outdoor and indoor sites a concentration of $\mathrm{Hg}^{0}<300$ (at $20^{\circ} \mathrm{C}$ and at $100 \mathrm{~cm}$ above the ground) and $<500$ (at $20^{\circ} \mathrm{C}$ and at $150 \mathrm{~cm}$ above the ground) $\mathrm{ng} \mathrm{\textrm {m } ^ { - 3 }}$, respectively, should not be exceeded.

In this respect, periodical measurements of GEM are necessary to proceed with the remediation since if the concentration limits are not overcome in some edifices and/or areas, no interventions are to be adopted, thus, allowing the financial resources to be allocated for the restoration of the most critical situations such as those expected in the edifices containing the furnaces and condensers.

\section{Sampling sites and analytical methods}

As previously stated, GEM measurements were carried out in May 2011 and were mainly concentrated in the Abbadia San Salvatore mining site and in the hydrothermal area of Bagni San Filippo (Fig. 1) due to the the conspicuous presence of thermal springs and dry gas vents (Frondini et al., 2009; Tassi et al., 2009). In the former site, an atmospheric Hg survey was also carried out inside the main edifices including the previous headquarters, dressing rooms, mechanical and electrical rooms, drying rooms, furnace buildings and other shelters and facilities. For comparison, $\mathrm{Hg}^{0}$ measurements were also conducted in two other mining areas (Siele and Morone) of Mt. Amiata that are located in the southern part of the volcanic edifice (Fig. 1).

Since the anomalous concentrations of mercury are not expected to be located only where the "quicksilver" was cultivated, transects along adjacent and external areas of the former mining zone were performed. Similarly, in order to verify whether gaseous mercury was reaching the town of Abbadia San Salvatore, located just few tens of meters south of the mining site, records of atmospheric mercury were also carried out in the urban area. Finally, GEM was also determined by car for long distance $\mathrm{Hg}^{0}$ surveys from Abbadia San Salvatore to Bagni San Filippo and to the old mining area of Morone (Fig. 1) passing close of the geothermal plant of Piancastagnaio, respectively.

Measurements of elemental mercury in air were performed using two portable Lumex $(915+$ and $\mathrm{M}$ ) analyzers for continuous GEM measurements. Analyzer operation is based on differential atomic absorption spectrometry using high-frequency modulation of light polarization (ZAAS-HFM) (Sholupov et al., 2004). The detection limit of the instrument for ambient air, industrial and natural gases is $2 \mathrm{ng} \mathrm{m}^{-3}$ at a flow rate through the instrument of $20 \mathrm{~L} \mathrm{~min}^{-1}$. The accuracy of the method is 20\% (Sholupov and Ganeyev, 1995). Application of Zeeman background correction and a multipath analytical cell provide high selectivity and sensitivity of measurements. The instrument allows determination of $\mathrm{Hg}$ in air directly with an ultra low detection limit in real time. This detection limit is governed by shot noise and equals $\mathrm{CaDL}=2 \mathrm{ng} \mathrm{m}^{-3}$ (average measuring time $=5 \mathrm{~s}$ ) and $\mathrm{CaDL}=0.3 \mathrm{ng} \mathrm{m}^{-3}$ (average measuring time $=30 \mathrm{~s}$ ) for mercury determination in air. The dynamic range covers four orders of magnitude $\left(2-50,000 \mathrm{ng} \mathrm{m}^{-3}\right)$. The real time measurements were made with visualization of the process on a digital display. On-line data recording was made by connecting the instrument to a lap-top computer. The whole process was completed in the field with geographic location of single data using a GPS. The statistical treatment of data was made using MINITAB 15.0, whereas the spatial distribution was plotted via SURFER 9.0.

At field scale the LUMEX-based measurement surveys were carried out in three different ways:

- Express surveys. Performed by using an automobile, with GPS control for each analysis position. The areas to cover were previously planned and all the local roads and tracks to cover the whole area with discrete sections were used during the surveys;

- Area network surveys. Consistent of measurements in a predetermined array of sites close to one of the described source areas, repeated at variable time intervals;

- Fixed point surveys. The device was located in a point of interest (close to the Nesa furnaces) for a predetermined time span, recording variations each $30 \mathrm{~s}$.

Meteorological data were collected by using a fully automatic Davis Vantage Vue station. In Table 1, temperature, wind direction and speed are reported. No abrupt variations in the climatic 
conditions were measured during the recordings, temperature and wind speed varying between 14.3 and $18.3^{\circ} \mathrm{C}$ and 1.2 and $3.6 \mathrm{~m} \mathrm{~s}^{-1}$, respectively. The prevailing winds were $\mathrm{W}$ and WNW oriented and no rainy episodes occurred.

\section{Results}

During the survey 35,598 measurements of atmospheric mercury were produced. The results are summarized in the logarithmic histogram of Fig. 2, while in Table 2 some statistical parameters, divided according to the different studied areas (Fig. 1), are reported. Generally speaking, the average value (325 $\mathrm{ng} \mathrm{m}^{-3}$ ), which includes both indoor and outdoor measurements, is slightly higher than that expected for $\mathrm{Hg}$ outdoor values if the Tuscany regulation is taken into account. The median value corresponds to $18 \mathrm{ng} \mathrm{m}^{-3}$ and does not coincide with the geometric mean ( $31 \mathrm{ng} \mathrm{m}^{-3}$ ). At least, four possible subpopulations can be recognized and are separated by threshold values of 40 , 160,500 and $1260 \mathrm{ng} \mathrm{m}^{-3}$ and likely derived by the large concentration differences encountered in the investigated sites.

Table 1

Average meteorological conditions in the sampling sites (Fig. 1) of the Abbadia San Salvatore mining district and surrounding areas.

\begin{tabular}{llllllll}
\hline \multirow{2}{*}{ Sampling } & \multicolumn{2}{l}{ Temperature $\left({ }^{\circ} \mathbf{C}\right)$} & & \multicolumn{2}{l}{ Wind } & Conditions \\
\cline { 2 - 3 } & Average & Min & Max & & Direction & Speed $\left(\mathrm{m} \mathrm{s}^{-1}\right)$ & \\
\hline BSF & 15.2 & 14.3 & 16.0 & WNW & 1.4 & Sunny \\
ASSU & 17.7 & 17.0 & 18.3 & WSW & 1.2 & Sunny \\
ASMA & 14.4 & 14.4 & 14.4 & WNW & 1.6 & Sunny \\
SMA & 14.7 & 14.3 & 15.0 & W & 3.6 & Sunny \\
MMA & 15.7 & 15.3 & 16.0 & W & 3.6 & Sunny \\
RIASM & 16.2 & 16.2 & 16.2 & W & 3.1 & Sunny \\
Fixed device & 15.9 & 14.3 & 17.3 & W & 3.5 & Indoor \\
& & & & & & &
\end{tabular}

BSF: Bagni San Filippo area; ASSU: Abbadia San Salvatore Urban area; ASMA: Abbadia San Salvatore Mining Area; SMA: Siele Mining Area; MMA: Morone Mining Area; RIASM: Road Itinerary Abbadia San Salvatore-Siele-Morone; fixed device was located for $5.5 \mathrm{~h}$ close to the Nesa furnace.
As expected, the highest $\mathrm{Hg}$ values are indeed found at ASMA (Abbadia San Salvatore Mining Area), SMA (Siele Mining Area), MMA (Morone Mining Area) where atmospheric Hg concentrations are up to $21,320,8159$ and $18,461 \mathrm{ng} \mathrm{m}^{-3}$, respectively, although it is worthwhile to mention that inside and close to the furnace and condenser areas, where 0.1 to $0.3 \mathrm{~m}$ wide pools of liquid $\mathrm{Hg}$ were observed, the portable $\mathrm{Hg}$ devices were saturated, indicating values $>50,000 \mathrm{ng} \mathrm{m}^{-3}$.

Mercury concentrations in the surrounding areas close to the former mining plants and downtown Abbadia San Salvatore achieved values similar to those recorded inside the decommissioned mining zones, although when the urban perimeter of Abbadia (ASSU in Table 2) is considered $\mathrm{Hg}^{0}$ values were always $<100 \mathrm{ng} \mathrm{m}^{-3}$. Interestingly, the Bagni San Filippo hydrothermal area showed low $\mathrm{Hg}$ concentrations, the highest value being $67 \mathrm{ng} \mathrm{m}^{-3}$, whilst the average was $12 \mathrm{ng} \mathrm{m}^{-3}$. Comparable values were recognized during express measurements in the road itineraries from Abbadia San Salvatore to Siele and Morone mining areas (RIASM in Table 2), i.e. average value: $13 \mathrm{ng} \mathrm{m}^{-3}$ with the highest concentrations up to $130 \mathrm{ng} \mathrm{m}^{-3}$, and to Bagni San Filippo, respectively. As mentioned, $\mathrm{Hg}$ measurements were also conducted inside the buildings (including those where cinnabar was roasted and liquid $\mathrm{Hg}$ was condensed and stored)

Table 2

Statistical parameters for the GEM concentrations (in $\mathrm{ng} \mathrm{m}^{-3}$ ) measured in the different sites of the Abbadia San Salvatore mining district and surrounding areas (Fig. 1).

\begin{tabular}{llcccl}
\hline Area & $N$ & Average & StDev & GeomAver & Maximum \\
\hline Whole area & 35,589 & 325 & 1470 & 31 & 21,320 \\
BSF & 4473 & 12 & 6.5 & 10 & 67 \\
ASSU & 7056 & 450 & 1652 & 88 & 21,320 \\
ASMA & 3644 & 735 & 2230 & 178 & 21,320 \\
SMA & 2422 & 239 & 650 & 75 & 8159 \\
MMA & 1073 & 2758 & 4009 & 594 & 18,461 \\
RIASM & 3362 & 13 & 15 & 9 & 130 \\
Fixed device & 1935 & 2710 & 3295 & 1470 & 29,841 \\
\hline
\end{tabular}

Acronyms as in Table 1. N: Number of determinations; StDev: standard deviation; GeomAver: geometric average.

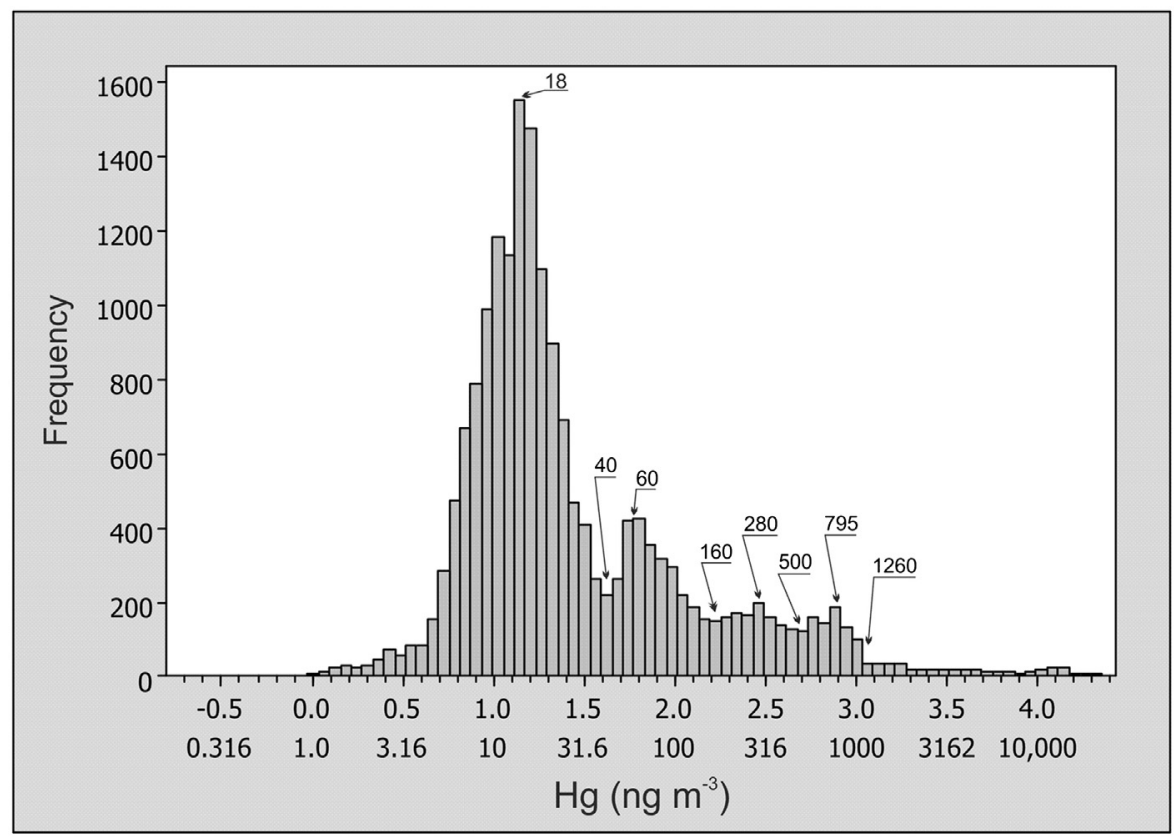

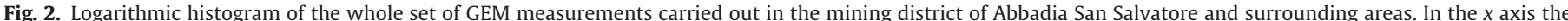
logarithmic (upper line) and the corresponding real (lower line) values are reported. 
of the mining area where highly variable concentrations were observed.

In Fig. 3 a schematic map of the buildings where $\mathrm{Hg}^{0}$ was analyzed is reported. Each color is referred to a specific interval of $\mathrm{Hg}$ concentrations and it was derived by hundreds of measurements carried out in each floor and/or room. Setting aside three buildings where $\mathrm{Hg}$ concentrations were characterized by values $<200 \mathrm{ng} \mathrm{m}^{-3}, 5$ sites have GEM between 200 and $1000 \mathrm{ng} \mathrm{m}^{-3}$, including the Mining Museum $\left(\mathrm{Hg}^{0}=625 \mathrm{ng} \mathrm{m}^{-3}\right)$, where cinnabar specimens and liquid mercury are stored, and 2 buildings are between 1000 and $2000 \mathrm{ng} \mathrm{m}^{-3}$ and 2000 and $5000 \mathrm{ng} \mathrm{m}^{-3}$, respectively. Eventually, the buildings containing the furnaces and the condensers had values that were comprised between 5000 and $10,000 \mathrm{ng} \mathrm{m}^{-3}$ and $>10,000 \mathrm{ng} \mathrm{m}^{-3}$. Such high concentrations are likely related to the presence of cinnabar-bearing rocks and liquid $\mathrm{Hg}$ still dropping from the old condenser devices.

On May 11, 2011, one of the portable instrumentations was left recording $\mathrm{Hg}$ concentrations in continuous for about $5.5 \mathrm{~h}$ (from 9.18 to 14.38 local time, $+2 \mathrm{~h}$ with respect to GMT) inside the reclamation area close to the Nesa furnaces, i.e. where ore material was roasted (Fig. 4). Arithmetic and geometric average concentrations were of 2710 and $1470 \mathrm{ng} \mathrm{m}^{-3}$, respectively, although the highest recorded value was of $29,841 \mathrm{ng} \mathrm{m}^{-3}$. As indicated by the mobile average of $\mathrm{Hg}$, corresponding to $30 \mathrm{~s}$, an enhancement of $\mathrm{Hg}$ concentrations as the solar radiation increases was observed, due to the volatility of $\mathrm{Hg}$ that increases with temperature, whereas a certain periodicity for the measured values can be attributed to wind oscillations.

\section{Discussion and conclusions}

The very first reliable data of $\mathrm{Hg}$ levels in the atmosphere of Mt. Amiata are by Ferrara et al. $(1982,1991)$ and Breder et al. (1983). More recently, Breder and Flucht (1984), Edner et al. (1993), Ferrara et al. (1998) and Bacci et al. (2000) have provided atmospheric $\mathrm{Hg}$ data close to both the geothermal plants and the mining areas of Abbadia San Salvatore, Siele and Morone. According to their data, obtained by sucking air on gold traps at a constant flow rate $\left(0.5-1 \mathrm{~L} \mathrm{~min}^{-1}\right)$ after which the amalgamated $\mathrm{Hg}$ was electrothermally desorbed and determined by AAS (Atomic Absorption Spectrophotometry) (e.g. Edner et al., 1993; Ferrara et al., 1998), the $\mathrm{Hg}$ concentrations in Abbadia San Salvatore area were recorded to be up to $1500 \mathrm{ng} \mathrm{m}^{-3}$ above the roasted cinnabar banks located at Le Lame, north of the mining area of Abbadia San Salvatore (Fig. 1). Furthermore, Ferrara et al. (1991) reported that in the Mt. Amiata region $\mathrm{Hg}^{0}$ ranged from 10 to $500 \mathrm{ng} \mathrm{m}^{-3}$ with the highest values recorded close to the ventilation system in the Abbadia San Salvatore mining area.

The application of a time-saving instrumentation such as the ZAAS-HFM is able to produce reliable data, highly comparable with those produced by CVAFAS (Cold Vapor Atomic Fluorescence Spectrometry), e.g. Kim et al. (2006); Aiuppa et al. (2007), allowing to investigate outdoor and indoor areas by acquiring a large number of concentrations that can statistically be treated, thus providing a substantial improvement with respect to the previous studies.

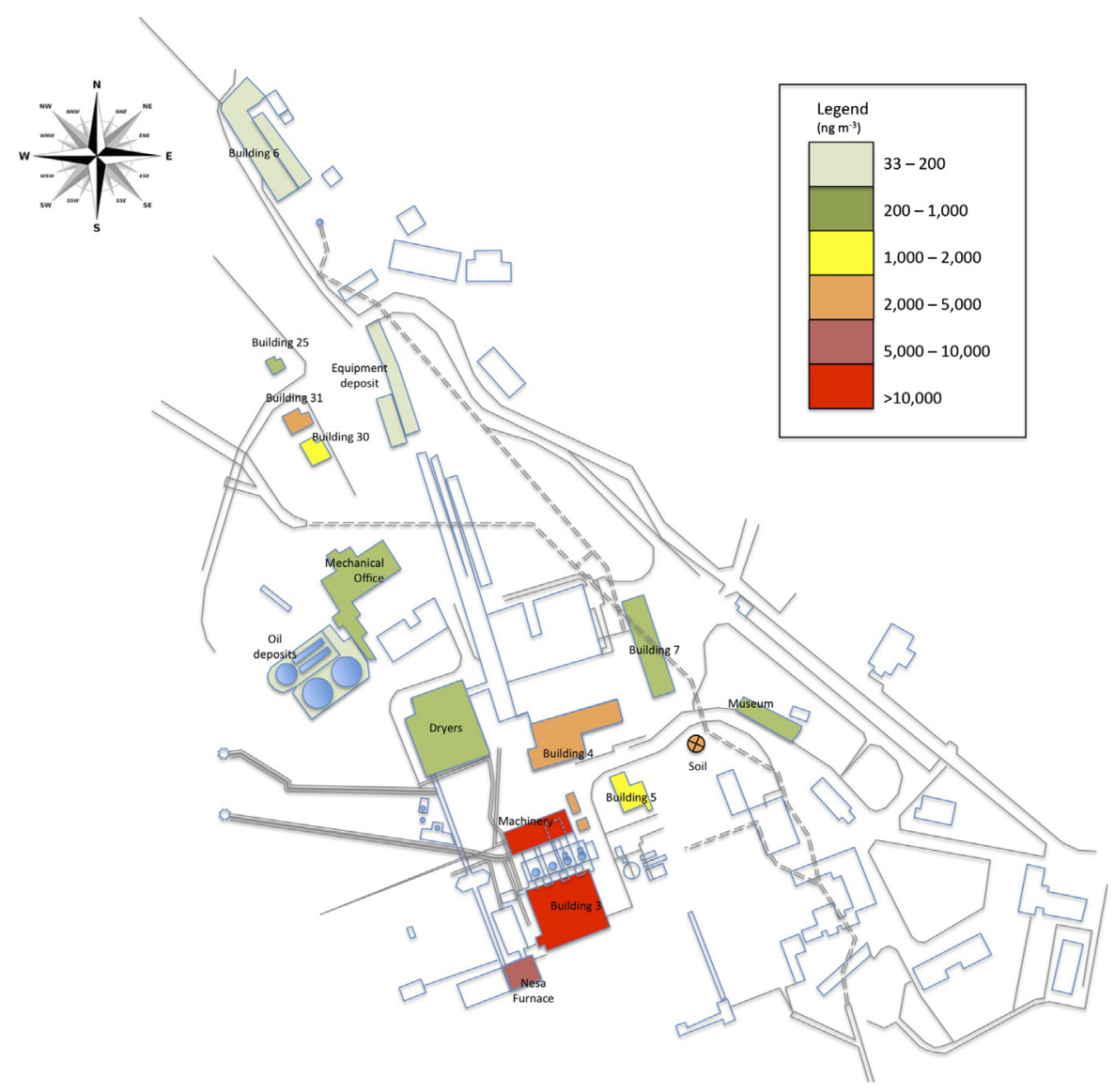

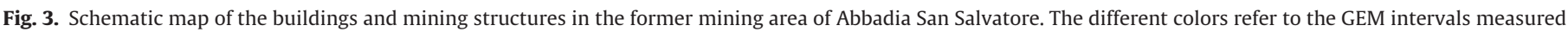

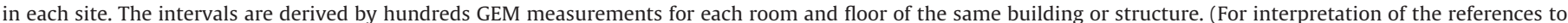
color in this figure legend, the reader is referred to the web version of this article.) 


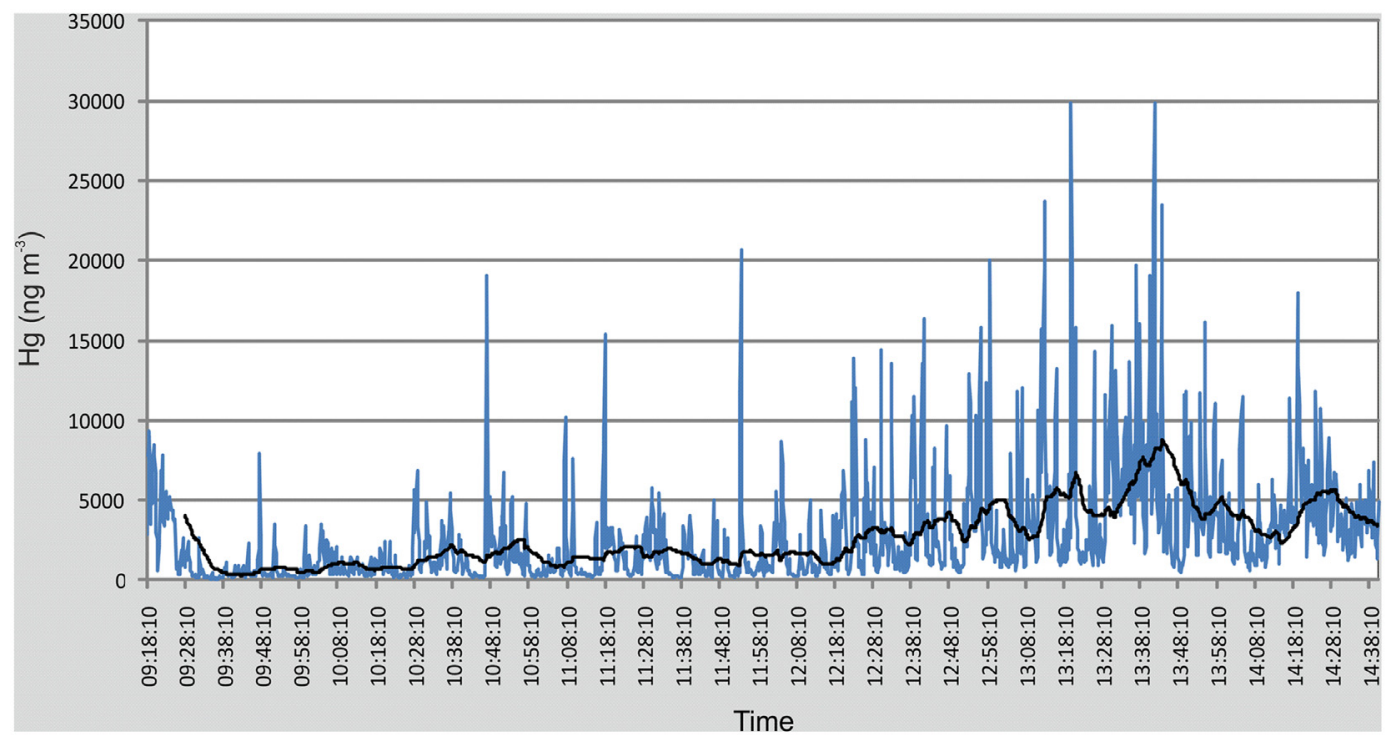

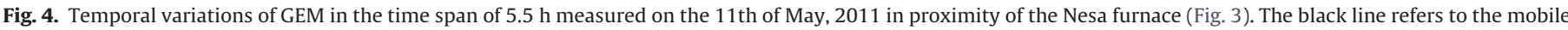
average corresponding to $30 \mathrm{~s}$, evidencing some periodicity in the $\mathrm{Hg}^{0}$ values, likely due to wind oscillations.

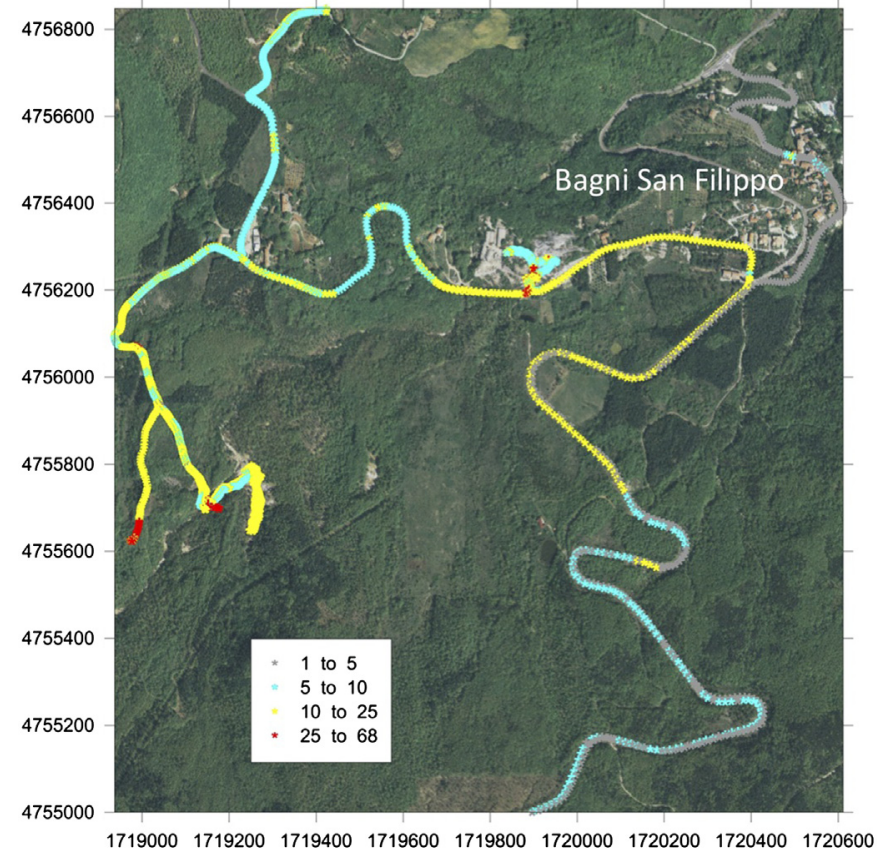

Fig. 5. Express survey along the main road that connects Abbadia San Salvatore to Bagni San Filippo. (For interpretation of the references to color in this figure legend, the reader is referred to the web version of this article).

The new data presented in the this work provide a better detail of the distribution of the gaseous mercury in the mining area of Abbadia San Salvatore, although limited to a defined period of time (May 2011) and highlight that the atmospheric mercury concentrations, particularly in those buildings still containing cinnabar and/or liquid $\mathrm{Hg}$, are much higher than those previously recorded (up to $>50,000 \mathrm{ng} \mathrm{m}^{-3}$ ) and that most of buildings have concentrations that abundantly overcome the limit values recommended by the local regulations in terms of outdoor (up to $300 \mathrm{ng} \mathrm{m}^{-3}$ and indoor (up to $500 \mathrm{ng} \mathrm{m}^{-3}$ )) Hg levels (Fig. 3). The differences in the $\mathrm{Hg}^{0}$ concentrations between Ferrara et al. (1991, 1998) and our data are likely due to the fact that the former were obtained in the proximity of the mining areas of

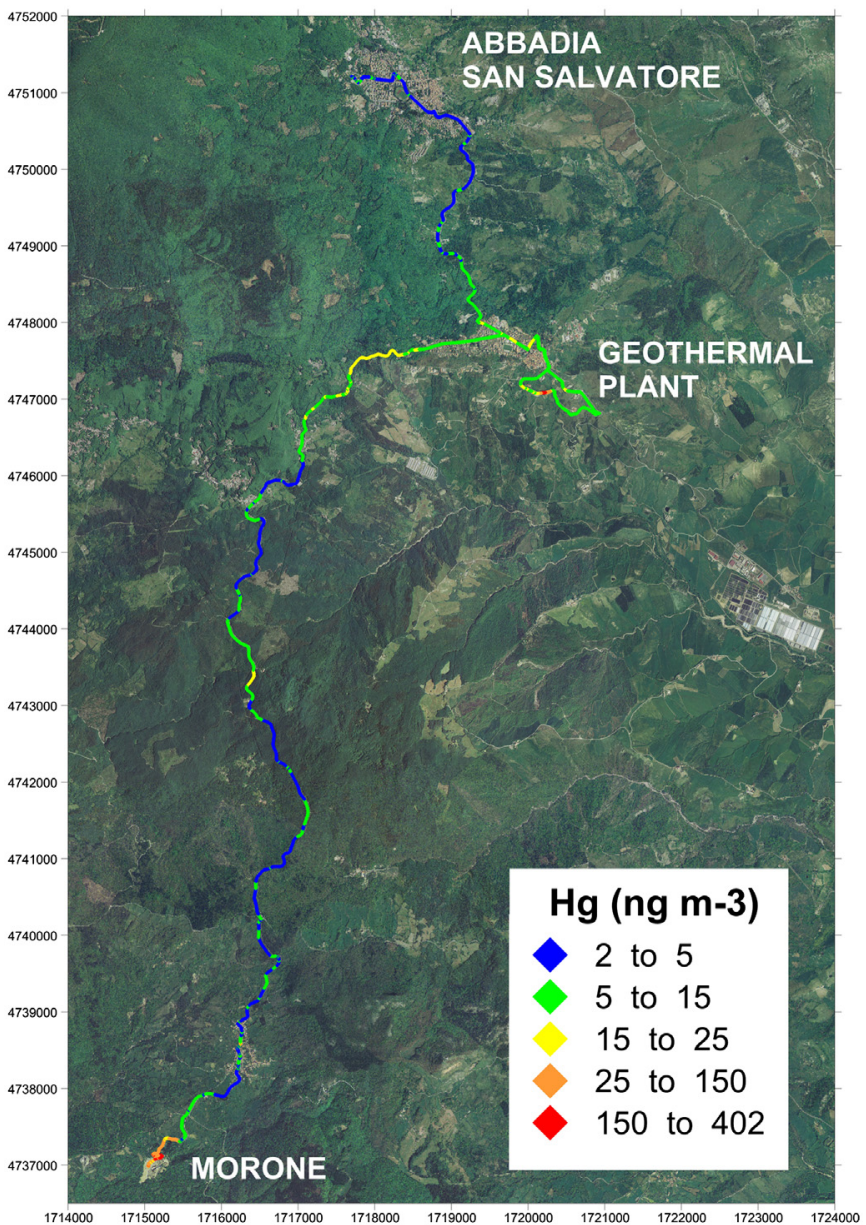

Fig. 6. Express survey along the main road that connects Abbadia San Salvatore to the Morone mine. (For interpretation of the references to color in this figure legend, the reader is referred to the web version of this article).

Abbadia San Salvatore, whereas in the present work we had the access to enter the mine structures and edifices. In 2008 the ownership of the reclamation was indeed transferred to the 
municipality of Abbadia San Salvatore and a collaboration between the Amiata locality and the Department of Earth Sciences was established in 2010 for monitoring the $\mathrm{Hg}^{0}$ concentration in the reclamation area.

According to Ferrara et al. (1998), mercury background values for Mt. Amiata can be referred to $3-5 \mathrm{ng} \mathrm{m}^{-3}$; however, these values are only partially achieved in the studied area as shown by the express surveys such as those carried out between Abbadia San Salvatore and Bagni San Filippo (Fig. 5) and between Abbadia San Salvatore and Morone mine (Fig. 6). In the former case, the background values are rarely maintained since $\mathrm{Hg}$ concentrations are between 10 and $68 \mathrm{ng} \mathrm{m}^{-3}$. As previously mentioned, in the Bagni San Filippo area $\mathrm{CO}_{2}$-rich dry gas vents, thermal water discharges, fossil and active travertine deposits and a thermal spa are present. It is highly likely that the significant increase of mercury as the village of Bagni San Filippo was approached can be referred to the presence of such thermal manifestations. After the village, mercury contents tend to slightly decrease and once again an increment is observed as we entered in the area where the largest gas emissions (Tassi et al., 2009) are encountered. To the best of our knowledge, no direct measurements in the gas discharges from this area are available but it can be speculated that the source of GEM can be related to these manifestations, also taking into account that nearby a $\mathrm{Hg}$ mine (the Pietrineri mine) was active until the seventies and, presently, the main entrance is cemented and two tubes (about one inch each in diameter) were inserted to favor the discharge into the air of the $\mathrm{CO}_{2}-\mathrm{H}_{2} \mathrm{~S}$-rich gas phase filling the mine (Vaselli et al., 2006).

The Abbadia San Salvatore-Morone express survey has shown a different pattern with respect to that of Abbadia San SalvatoreBagni San Filippo. The concentrations of atmospheric $\mathrm{Hg}$ are indeed in the same order of magnitude of the background values of Mt. Amiata, mainly being $<10 \mathrm{ng} \mathrm{m}^{-3}$. Occasionally, slight increase in mercury (ca. $150 \mathrm{ng} \mathrm{m}^{-3}$ ) was observed around Piancastagnaio, possibly due to the discharging fumes from the local geothermal plant, which is considered responsible of $\mathrm{Hg}$ pollution of the area since concentrations up to $1000 \mathrm{ng} \mathrm{m}^{-3}$ were found at a height of $20-30 \mathrm{~m}$ from the ground (Ferrara et al., 1998). Eventually, values between 5 and $15 \mathrm{ng} \mathrm{m}^{-3}$ were also recorded approaching the Morone mining areas. Here, $\mathrm{Hg}^{0}$ concentrations up to $400 \mathrm{ng} \mathrm{m}^{-3}$ were achieved (Fig. 6).

A different and more complex picture is obtained by considering the contour map of atmospheric mercury (in $\mathrm{ng} \mathrm{m}^{-3}$ ) in the former mining block, including the urban area of Abbadia San Salvatore (Fig. 7). This picture improves and better characterizes the previous maps published by Ferrara et al. (1998). In particular, Abbadia San Salvatore does not appear to be substantially affected by the edifices containing the furnaces and the condenser

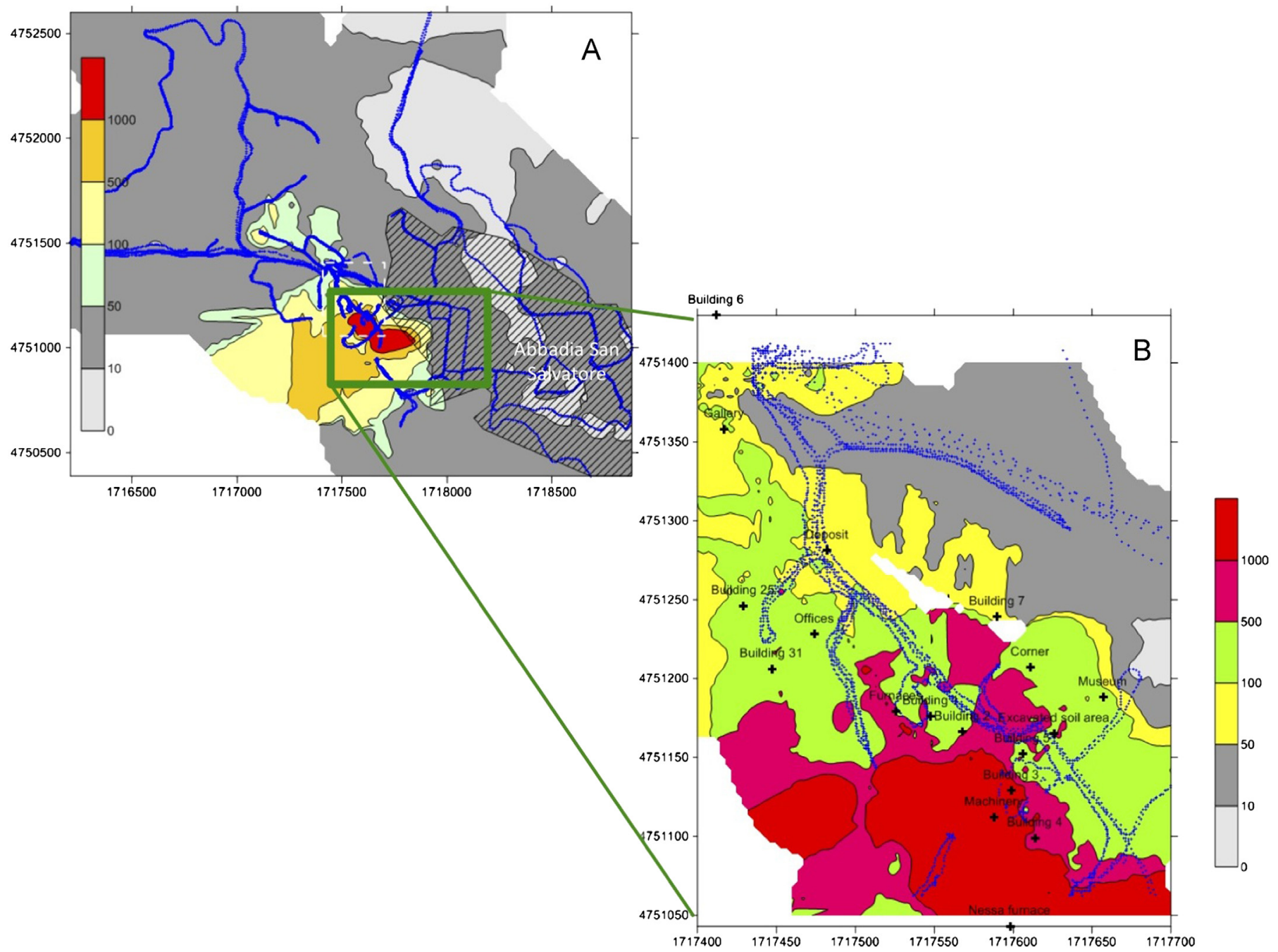

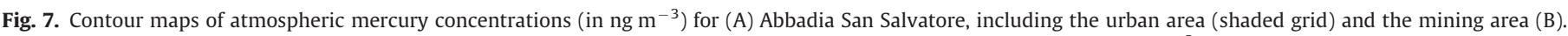

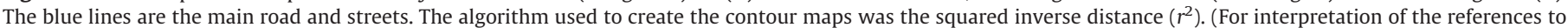
color in this figure legend, the reader is referred to the web version of this article.) 
pipelines, although intervals of $\mathrm{Hg}$ between 10 and 50 in $\mathrm{ng} \mathrm{m}^{-3}$ were measured. On the opposite side with respect to the mining zone a sort of $\mathrm{Hg}$ plume can be observed and centered in the $\mathrm{Hg}$ rich premises (Fig. 7), with values $>1000$ in $\mathrm{ng} \mathrm{m}^{-3}$, which tend to waning below the recommended limits (300 in $\mathrm{ng} \mathrm{m}^{-3}$ ) for open air areas in about $500 \mathrm{~m}$.

Gaseous mercury concentrations in the Mt. Amiata mining area are similar to those observed in other mercury districts, such as Almadén (Spain) (e.g. Higueras et al., 2006) and Idrija (Slovenia) (e.g. Kocman et al., 2011). High $\mathrm{Hg}^{0}$ values are observed in the close proximity of the former mining facilities, whilst they tend to decrease quite abruptly from the source areas. Healthy concerns can perhaps only be related to those people living close to the perimeter of the mining district although detailed epidemiologic studies, similar to those carried out by Bellander et al. (1998) on the workers involved in the smelting process at Abbadia San Salvatore, should be performed before any alarming echoes. In our study, $\mathrm{Hg}^{0}$ values above the Tuscany regulations (300 $\mathrm{ng} \mathrm{m}^{-3}$ ) were indeed only found in the mining facilities, whereas in the urban area GEM is below the maximum recommended level for chronic exposition.

Most importantly, it is the fact that the reclamation project in the mining area of Abbadia San Salvatore is about to be commenced. This will imply that for each step, including removal of the furniture, instrumentations, machineries, inert material and restoration or destructions of the edifices, a monitoring program on the quality of air has to be planned. In this respect, the application of the ZAAS-HFM technique can also be used to identify $\mathrm{Hg}^{0}$-emitters located in the rooms and warehouses of the different buildings.

Both continuous measurements of atmospheric mercury and particulate in order to avoid the dispersion of pollutants to the nearby Abbadia San Salvatore are to be taken into accounts to avoid or minimize any risks deriving from the dispersion of the GEM and PBM.

\section{Acknowledgments}

The Authors wish to acknowledge Dr. E. Kovner Silbergeld and two anonymous reviewers who improved the earlier version of the manuscript.

Many thanks to the municipality of Abbadia San Salvatore for permitting to enter the former mining areas and the related edifices. Marcello Niccolini is warmly thanked for his support in the field.

\section{References}

Acocella, V., 2000. Space accommodation by roof lifting during pluton emplacement ad Amiata Monte (Italy). Terra Nova 12, 149-155.

Aiuppa, A., Bagnato, E., Witt, M.L.I., Mather, T.A., Parello, F., Pyle, D.M., Martin, R.S. 2007. Real-time simultaneous detection of volcanic $\mathrm{Hg}$ and $\mathrm{SO}_{2}$ at La Fossa Crater, Vulcano (Aeolian Islands, Sicily). Geophys. Res. Lett. 34, L21307, http:// dx.doi.org/10.1029/2007GL030762.

Bacci, E., Gaggi, C., Duccini, M., Bargagli, R., Renzoni, A., 1994. Mapping mercury vapours in an abandoned cinnabar mining area by azalea (Azalea indica) leaf trapping. Chemosphere 29, 641-656.

Bacci, E., Gaggi, C., Lanzillotti, E., Ferrozzi, S., Valli, L., 2000. Geothermal power plants at Mt. Amiata (Tuscany-Italy): mercury and hydrogen sulphide deposition revealed by vegetation. Chemosphere 40, 907-911.

Bacci, E., Renzoni, A., 1973. Preliminary research on the content of total mercury in some fish of Monte Amiata rivers. Rass. Med. Sper. 20, 60-67. (in Italian).

Barghigiani, C., Ristori, T., 1994. The distribution of mercury in a Mediterranean area. In: Watras, C.J., Huckabee, J.W. (Eds.), Mercury Pollution: Integration and synthesis, 1994. Lewis Publishers, Boca Raton, pp. 41-49.

Bellander, T., Merler, E., Ceccarelli, F., Boffetta, P., 1998. Historical exposure to inorganic mercury at the smelter works of Abbadia San Salvatore, Italy. Ann. Occup. Hyg. 42, 81-90.

Boening, D.W., 2000. Ecological effects, transport and fate of mercury: a general review. Chemosphere 40, 1335-1351.
Breder, R., Flucht, R., 1984. Mercury levels in the atmosphere of various regions and locations in Italy. Sci. Total Environ. 40, 231-244.

Breder, R., Flucht, R., Ferrara, R., Barghigiani, C., Seritti, A., 1983. Mercury levels in the air of a Mediterranean area. In: Farmer, J.G. (Ed.), Proceedings of the International Conference on Heavy Metals in the Environment, Heidelberg, EP Consultants Ltd., Edinburgh, pp. 151-154.

Brogi, A., Fabbrini, L., Liotta, D., 2011. Sb-Hg ore deposit distribution controlled by brittle structures: the case of the Selvena mining district (Monte Amiata, Tuscany, Italy). Ore Geol. Rev. 41, 35-48.

Cipriani, C., Tanelli, G., 1983. Risorse minerarie ed industria estrattiva in Toscana. Note storiche ed economiche. Atti e Memorie Accademia di Scienze e Lettere La Colombaria 28, 241-283. (in Italian)

Conticelli, S., Melluso, L., Perini, G., Avanzinelli, R., Boari, E., 2004. Petrologic geochemical and isotopic characteristics of potassic and ultrapotassic magmatism in Central-Southern Italy: inferences on its genesis and on the nature of mantle sources. Per. Mineral. 73, 135-164.

Dini, A., Benvenuti, M., Costagliola, P., Lattanzi, P., 2001. Mercury deposits in metamorphic settings: the example of Levigliani and Ripa mines (Apuane Alps, Tuscany, Italy). Ore Geol. Rev. 18, 149-167.

Dini, A., Gianelli, G., Puxeddu, M., Ruggieri, G., 2005. Origin and evolution of Pliocene-Pleistocene granites from the Larderello geothermal field (Tuscan Magmatic Province, Italy). Lithos 81, 1-31.

Edner, H., Ragnarson, P., Svanberg, S., Wallinder, E., Ferrara, R., Maserti, B.E., Bargagli, R., 1993. Atmospheric mercury mapping in a cinnabar mining area. Sci. Total Environ. 133, 1-15.

Frondini, F., Caliro, S., Cardellini, C., Chiodini, G., Morgantini, N., 2009. Carbon dioxide degassing and thermal energy release in the Monte Amiata volcanicgeothermal area (Italy). Appl. Geochem. 24, 860-875.

Ferrara, R., Maserti, B.E., Breder, R., 1991. Mercury in abiotic and biotic compartments of an area affected by a geochemical anomaly (Mt. Amiata, Italy). Water Air Soil Pollut. 56, 219-233.

Ferrara, R., Maserti, B.E., Andersson, M., Edner, H., Ragnarson, P., 1997. Mercury degassing rate from mineralized areas in the Mediterranean Basin. Water Air Soil Pollut. 93, 59-66.

Ferrara, R., Mazzolai, U.B., Edner, H., Svanberg, S., Wallinder, E., 1998. Atmospheric mercury sources in the Mt. Amiata area, Italy. Sci Total Environ. 213, 12-23.

Ferrara, R., Petrosino, A., Maserti, B.E., Seritti, A., Barghigiani, C., 1982. The biogeochemical cycle of mercury in the Mediterranean. Part 2: mercury in the atmosphere, aerosol and in rainwater of a northern Tyrrhenian are. Environ. Technol. Lett. 3, 449-456.

Ferrari, L., Conticelli, S., Burlamacchi, L., Manetti, P., 1996. New geologic and volcanological data on the Mt. Amiata silicic complex. Acta Vulcanol. 8, 41-56.

Fu, X.W. Feng, X. Shang, L.H. Wang, S.F., Zhang, H., 2012. Two years of measurements of atmospheric total gaseous mercury (TGM) at a remote site in Mt. Changbai area, Northeastern China. Atmos. Chem. Phys. 12, 4215-4226.

Gianelli, G., Puxeddu, M., Batini, F., Bertini, G., Dini, I, Pandeli, E., Nicolich, R., 1988 Geological model of a young volcano-plutonic system: the geothermal region of Monte Amiata (Tuscany, Italy). Geothermics 17, 719-734.

Gosar, H., Pirc, S., Bidovec, M., 1997. Mercury in the Idrija river sediments as a reflection of mining and smelting activities of the Idrija mercury mine. J. Geochem. Explor. 58, 125-131.

Gray, J.E., 2003. Leaching, transport, and methylation of mercury in and around abandoned mercury mines in the Humboldt River basin and surrounding areas, Nevada. US Geol. Surv. Bull. 2210-C.

Gray, J.E., Crock, J.G., Fey, D.L., 2002. Environmental geochemistry of abandoned mercury mines in West-Central Nevada, USA. Appl. Geochem. 17, 1069-1079.

Gray, J.E., Plumlee, G.S., Morman, S.A., Higueras, P.L., Crock, J.G., Lowers, H.A. Witten, M.L., 2010. In vitro studies evaluating leaching of mercury from mine waste calcine using simulated human body fluids. Environ. Sci. Technol. 44, 4782-4788.

Gray, J.E., Hines, M.E., Higueras, P.L., Adatto, I., Lasorsa, B.K., 2004. Mercury speciation and microbial transformations in mine wastes, stream sediments, and surface waters at the Almaden mining district, Spain. Environ. Sci. Technol. 38, 4285-4292.

Grönlund, R., Edner, H., Svanberg, S., Kotnik, J., Horvat, M., 2005. Mercury emissions from the Idrija mercury mine measured by differential absorption lidar techniques and a point monitoring absorption spectrometer. Atmos. Environ. 39, 4067-4074.

Higueras, P., Esbrí, J.M., Oyarzun, R., Llanos, W., López-Berdonces, M.A., MartínezCoronado, A., García Noguero, E.M., Industrial and natural sources of gaseous elemental mercury in the Almadén District (Spain): An updated report on this issue after the cease of mining and metallurgical activities in 2003 and major land reclamation works. Environ. Res. http://dx.doi.org/10.1016/j.envres.2012.10.011, in press.

Higueras, P., Llanos, W., García, M.E., Millán, R., Serrano, C., 2012. Mercury vapor emissions from the Ingenios in Potosí (Bolivia). J. Geochem. Explor. 116-117 $1-7$.

Higueras, P., Oyarzun, R., Lillo, J., Sánchez-Hernández, J.C., Molina, J.A., Esbrí, J.M., Lorenzo, S., 2006. The Almadén district (Spain): anatomy of one of the world's largest Hg-contaminated sites. Sci. Total Environ. 236, 112-124.

Hines, M.E., Horvat, M., Faganeli, J., Bonzongo, J.J., Barkay, T., Major, E.B., Scott, K.J., Bailey, E.A.., Warwick, J.J., Lyons, W.B., 2000. Mercury biogeochemistry in the Idrija River, Slovenia, from above the mine into the Gulf of Trieste. Environ. Res. Sec. A 83, 129-139. 
Hylander, L.D., Meili, M., 2003. 500 years of mercury production: global annual inventory by region until 2000 and associated emissions. Sci. Total Environ. 304, 13-27.

Kim, C.S., Bloom, N.S., Rytuba, J.J., Brown Jr., G.E., 2003. Mercury speciation by $\mathrm{X}$-ray absorption fine structure spectroscopy and sequential chemical extrac tions: a comparison of speciation methods. Environ. Sci. Technol. 37, 5102-5108.

Kim, Ki.-H., Mishra, V.K., Hong, S., 2006. The rapid and continuous monitoring of gaseous elemental mercury (GEM) behavior in ambient air. Atmos. Environ. 40, 3281-3293.

Kocman, D., Vreča, P., Fajon, V., Horvat, M., 2011. Atmospheric distribution and deposition of mercury in the Idrija Hg mine region, Slovenia. Environ. Res. 111, $1-9$.

Lindberg, S., Bullock, R., Ebinghaus, R., Engstrom, D., Feng, X., Fitzgerald, W., Pirrone, N., Prestbo, E., Seigneur, Ch., 2007. A synthesis of progress and uncertainties in attributing the sources of mercury in deposition. Ambio 36, $19-32$.

Loppi, S., 2001. Environmental distribution of mercury and other trace elements in the geothermal area of Bagnore (Mt. Amiata, Italy). Chemosphere 45, 991-995.

Loppi, S., Bonini, I., 2000. Lichens and mosses as biomonitors of trace elements in areas with thermal springs and fumarole activity (Mt. Amiata, central Italy). Chemosphere 41, 1333-1336.

Loredo, J., Pereira, A., Ordóñez, A., 2003. Untreated abandoned mercurymining works in a scenic area of Asturias (Spain). Environ. Int. 29, 481-491.

Minissale, A., Magro, G., Vaselli, O., Verrucchi, C., Perticone, I., 1997. Geochemistry of water and gas discharges from the Mt. Amiata silicic complex and surrounding areas (Central Italy). J. Volcanol. Geotherm. Res. 79, 223-251.

Morteani, G., Ruggieri, G., Möller, P., Preinfalk, C., 2010. Geothermal mineralized scales in the pipe system of the geothermal Piancastagnaio power plant (Monte Amiata geothermal area): a key to understand the stibnite, cinnabarite and gold mineralization of Tuscany (Central Italy). Miner. Dep. 46, 197-210.

Navarro, A., Cardellach, E., Corbella, M., 2009. Mercury mobility in mine waste from $\mathrm{Hg}$ mining areas in Almería, Andalusia (Se Spain). J. Geochem. Explor. $101,236-246$.

Qiu, G., Feng, X., Wang, S., Fu, X., Shang, L., 2009. Mercury distribution and speciation in water and fish from abandoned $\mathrm{Hg}$ mines in Wanshan, Guizhou province, China. Sci. Total Environ. 407, 5162-5168.

Regoli, R., Berni, S., 2001. Finding of crystallized cinnabar alongside the Farma River (Siena Tuscany). Atti Museo di Storia Naturale Maremmana 19, 141-147. (in Italian).

Rimondi, V., Gray, J.E., Costagliola, P., Vaselli, O., Lattanzi, P., 2012. Concentration, distribution, and translocation of mercury and methylmercury in mine-waste, sediment, soil, water, and fish collected near the Abbadia San Salvatore mercury mine, Monte Amiata district, Italy. Sci. Total Environ. 414, 318-327.

Rytuba, J.J., 2000. Mercury mine drainage and processes that control its environmental impact. Sci. Total Environ. 260, 57-71.

Rytuba, J.J., Kotlyar, B.B., Wilkerson, G., Olson, J., 2001. Geochemistry of selected mercury mine-tailings in the Parkfield Mercury district, California. USGS, Open-File Report 01-336, version 1.0.

Schroeder, W.H., Munthe, J., 1998. Atmospheric mercury-an overview. Atmos. Environ. 32, 809-822.

Sestini, F., 1932. Il mare pliocenico della Toscana meridionale. In: Dainelli, G., (Ed.), Mem. Geol. Geogr. 2.

Sholupov, S.E., Ganeyev, A.A., 1995. Zeeman atomic absorption spectrometry using high frequency modulated light polarization. Spectrochim. Acta, Part B 50 , 1227-1236.

Sholupov, S., Pogarev, S., Ryzhov, V., Mashyanov, N., Stroganov, A., 2004. Zeeman atomic absorption spectrometer RA-915+ for direct determination of mercury in air and complex matrix samples. Fuel Process. Technol. 85, 473-485.

Stein, E.D., Cohen, Y., Winer, A.M., 1996. Environmental distribution and transformation of mercury compounds. Crit. Rev. Environ. Sci. Technol. 26, 1-43.

Strappa, D., 1977. Storia delle miniere di mecurio del M. Amiata. Ind. Min. 28, 252-259. (in Italian).

Tanelli, G., 1983. Mineralizzazioni metallifere e minerogenesi della Toscana.Mem. Soc. Geol. Italy 25, 91-109. (in Italian with English abstract).

Tassi, F., Vaselli, O., Cuccoli, F., Buccianti, A., Nisi, B., Lognoli, E., Montegrossi, G., 2009. A geochemical multi-methodological approach in hazard assessment of $\mathrm{CO}_{2}$-rich gas emissions at Mt. Amiata volcano (Tuscany, central Italy). Water Air Soil Pollut. Focus 9, 117-127.

Vaselli, O., Cuccoli, F., Buccianti, A., Nisi, B., Lognoli, E., Lombardi, L., Moretti, S., Capannesi, L., Ramaldi, E., Tassi, F., Montegrossi, G., Capaccioni, B., Minissale, A., 2006. Le emanazioni gassose nel Comune di Castiglione d'Orcia. Relazione finale della Convenzione tra il Dipartimento della Protezione Civile della Regione Toscana e il Dipartimento di Scienze della Terra dell'Università di Firenze, Luglio 2006, p. 120. (in Italian).

Vaselli, O., Nisi, B., Tassi, F., Rappuoli, D., Pancioli, V., Ucciero, S., Giannini, L., 2011. $\mathrm{CO}_{2}$ hazard vs. touristic attraction at the Mt. Amiata volcano (Italy). Acta Vulcanol. 23, 71-78.

Wilson, S.J., Steenhuisen, F., Pacyna, J.M., Pacyna, E.G., 2006. Mapping the spatial distribution of global anthropogenic mercury atmospheric emission inventories. Atmos. Environ. 40, 4621-4632.

Zhang, G., Liu, C.Q., Wu, P., Yang, Y., 2004. The geochemical characteristics of minewaste calcines and runoff from the Wanshan mine, Guizhou, China. Appl. Geochem. 19, 1735-1744. 